\title{
Effect of estrogen on molecular and functional characteristics of the rodent vaginal muscularis
}

\author{
Maureen E. Basha, PhD ${ }^{1}$, Shaohua Chang, PhD², Lara J. Burrows, MD, MSc ${ }^{3}$, Jenny \\ Lassmann, MD ${ }^{4}$, Alan J. Wein, MD ${ }^{2}$, Robert S. Moreland, PhD $^{2,5}$, and Samuel K. Chacko, \\ DVM, PhD ${ }^{2}$ \\ ${ }^{1}$ Department of Human Science, School of Nursing and Health Studies, Georgetown University \\ ${ }^{2}$ Department of Surgery, Division of Urology, University of Pennsylvania School of Medicine, \\ Philadelphia, PA, 19104 \\ ${ }^{3}$ Department of Obstetrics and Gynecology, Summa Health System, Akron, $\mathrm{OH}$ \\ ${ }^{4}$ Department of General Pediatrics, Division of Urology, Children's Hospital of Philadelphia, \\ Philadelphia, PA \\ ${ }^{5}$ Department of Pharmacology and Physiology, Drexel University College of Medicine, \\ Philadelphia, PA, 19102
}

\begin{abstract}
Introduction-Vaginal atrophy is a consequence of menopause however little is known concerning the effect of a decrease in systemic estrogen on vaginal smooth muscle structure and function. As the incidence of pelvic floor disorders increases with age, it is important to determine if estrogen regulates the molecular composition and contractility of the vaginal muscularis.
\end{abstract}

Aim-The goal of this study was to determine the effect of estrogen on molecular and functional characteristics of the vaginal muscularis utilizing a rodent model of surgical menopause.

Methods-3-4 month old Sprague Dawley rats underwent sham laparotomy (Sham, $n=18$ ) or ovariectomy (Ovx, $\mathrm{n}=39)$. Two weeks following surgery, animals received a subcutaneous osmotic pump containing vehicle (Sham, Ovx) or 17- $\beta$ estradiol (Ovx). Animals were euthanized one week later and the proximal vagina was collected for analysis of contractile protein expression and in vitro studies of contractility. Measurements were analyzed using a one-way ANOVA followed by Tukey's post hoc analysis $(a=0.05)$.

Main Outcome Measures-Protein and mRNA transcript expression levels of contractile proteins, in vitro measurements of vaginal contractility

Results-Ovariectomy decreased the expression of carboxyl-terminal myosin heavy chain isoform SM1 and $h$-caldesmon and reduced the amplitude of contraction of the vaginal muscularis in response to $\mathrm{KCl}$. Estradiol replacement reversed these changes. No differences were detected in the \% vaginal muscularis, mRNA transcript expression of amino terminal MHC isoforms, $l-$ caldesmon expression and maximal velocity of shortening.

Conclusion-Systemic estrogen replacement restores functional and molecular characteristics of the vaginal muscularis of ovariectomized rats. Our results indicate that menopause is associated

Address of individual responsible for reprint requests and corresponding author: Dr. Maureen Basha, Dept. of Human Science, School of Nursing and Health Studies, 251 St. Mary's Hall, Georgetown University, 3700 Reservoir Road NW, Washington DC 20057, Tel 202687 4221, Fax 202687 5553, meb288@georgetown.edu.

Disclosure: None of the authors have a conflict of interest. 
with changes in the vaginal muscularis, which may contribute to the increased incidence of pelvic floor disorders with age.

\section{Introduction}

Although it is well known that decreases in ovarian hormone levels with menopause lead to vaginal atrophy, the molecular and functional changes of the vaginal wall in response to ovarian hormone deprivation are only partially described. In order to further delineate the effect of ovarian hormones on vaginal structure and function, studies have been conducted with ovariectomized animals as a model of surgical menopause. Results of these studies have demonstrated changes in collagen distribution $(1 ; 2)$, abundance of nonvascular smooth muscle (3;4), steroid hormone receptor expression (5) and innervation (6) within the vaginal wall. Physiological changes such as reduced vaginal blood flow (7), decreased contractility of the distal vaginal muscularis $(8 ; 9)$, and altered biomechanical properties of the vagina (10) have also been demonstrated. These studies provide compelling evidence that vaginal changes with menopause may compromise pelvic organ support and female sexual function. Despite evidence of molecular changes within the vaginal muscularis of women with pelvic organ prolapse (POP), little is known regarding the effect of ovarian hormone loss on contractile protein expression within this non-vascular smooth muscle layer.

Myosin, the molecular motor of contraction, is a hexamer consisting of two heavy chains (myosin heavy chain: MHC), two phosphorylatable 20kDa light chains and two $17 \mathrm{kDa}$ essential light chains. Four isoforms of MHC are formed by alternative splicing of a single gene (11-13). Alternative splicing at the 5' end of pre-mRNA forms two isoforms (SM-A, SM-B) of MHC that differ in their amino terminal sequence $(11 ; 13 ; 14)$. The SM-B isoform contains a seven amino acid insert near the ATP binding site of the myosin head and has been shown to correlate with a higher rate of shortening velocity (an estimate of myosin ATPase activity) as compared to the SM-A isoform which lacks this insert (15-19). Alternative splicing of pre-mRNA at the 3' end results in the formation of isoforms that contain either a 9 amino acid (SM2) or 43 amino acid (SM1) carboxyl terminus sequence $(12 ; 20 ; 21)$. Expression of SM1/SM2 within bladder, uterine and aortic smooth muscle has been reported to be regulated by estrogen (22-25). As smooth muscle demonstrates tissue heterogeneity, it is necessary to also determine the effect of ovarian hormone loss on MHC isoform expression within the vaginal muscularis. The functional significance of SM1/SM2 expression is unresolved $(16 ; 26-31)$ and it is therefore difficult to determine the consequence of hormonally mediated changes in MHC.

Expression of the thin filament associated protein, caldesmon, has also been shown to be hormonally regulated (32). Caldesmon exists as two isoforms formed by alternative splicing of a single gene. $h$-Caldesmon (high MW, $120-150 \mathrm{kDa}$ ) is a smooth muscle specific isoform and $l$-caldesmon (low MW, 70-80 kDa) is an isoform expressed in most vertebrate cells $(33 ; 34)$. Lin et al. (32) reported decreases in $h$-caldesmon expression within detrusor smooth muscle of ovariectomized rabbits, with time dependent changes in expression following estrogen replacement. Pregnancy has also been shown to alter $h$-caldesmon expression within the myometrium of both mice (35) and humans (36-38), lending further evidence of sex steroid regulation of this contractile protein.

Smooth muscle fibers from the vaginal wall have been demonstrated to be a component of the endopelvic fascia that attaches the vagina to the levator ani (39). This structural feature of vaginal smooth muscle and vaginal smooth muscle tone have been hypothesized to play a role in pelvic organ support. Human studies using biopsies obtained from the vaginal cuff of patients with POP have shown a decrease in the fractional area of smooth muscle within the vaginal muscularis (40-43) and altered contractility in response to $\mathrm{KCl}$ stimulation (40). 
Interestingly, changes in caldesmon gene and protein expression within the vaginal muscularis of POP patients have also been reported although the results are conflicting $(42 ; 44 ; 45)$. It is important to note that age, parity, and hormonal status are risk factors for POP. It is therefore possible that the discrepancy in results could be related to the difficulty in controlling for these factors in human studies. Further research is needed to clarify the effect of POP and menopause on the vaginal muscularis.

Regional differences have been reported between the proximal and distal vagina $(18 ; 46-50)$. Importantly, animal models of female sexual arousal have illustrated in vivo regional differences vaginal contractility, and histological studies have demonstrated that the vaginal muscularis is more abundant in the proximal vagina $(18 ; 51)$. Although ovarian hormone regulation of vaginal blood flow and distal vaginal contractility has been described, the effect of ovarian hormones on proximal vaginal contractility has yet to be determined. The goals of this study were to determine the molecular and functional changes of the proximal vaginal muscularis in a rodent model of surgical menopause and the efficacy of systemic estrogen replacement in reversing changes associated with the loss of ovarian function. We have focused our study on the ovarian hormone, estrogen, as it is the currently FDA approved hormone for treating vulvovaginal atrophy with menopause. Results obtained from this study will further our understanding of the effect of menopause on the female sexual response and pelvic organ support.

\section{Materials and Methods}

\section{Animals}

Animal use and the experimental protocol were approved by the Institutional Animal Care and Use Committee of Drexel University College of Medicine. Sham-operated (sham) and bilaterally ovariectomized (ovx) female Sprague-Dawley rats (3- 4 months old, 250-300 grams) were obtained from a commercial supplier and housed in a temperature $\left(25^{\circ} \mathrm{C}\right)$ and light-controlled (12h light/12h dark) room, with free access to food and water. Two weeks post-surgery, an osmotic pump (Alzet, Model 2002) was placed subcutaneously between the scapulae containing either $0.9 \%$ saline (sham, ovx) or cyclodextran-encapsulated $17 \beta$ estradiol (ovx). 17- $\beta$ estradiol was replaced at a delivery rate of $10 \mu \mathrm{g} / \mathrm{kg} /$ day. One week following pump placement, animals were heavily sedated with ketamine $(75 \mathrm{mg} / \mathrm{kg})$ and xylazine $(10 \mathrm{mg} / \mathrm{kg})$, the thoracic cavity was exposed, and blood was collected from the heart for analysis of serum levels of 17- $\beta$ estradiol by RIA (Cornell University, Animal Health Diagnostic Center). Animals were then euthanized by exsanguination and the abdominopelvic cavity was exposed. Ovariectomy was confirmed visually and the uterus was dissected and weighed. The vagina was dissected and cleaned of connective tissue for molecular and physiological studies.

\section{Vaginal Tissue Preparation}

For histological procedures, the vagina was placed in Histochoice fixative (Amresco, Solon, $\mathrm{OH}$ ) and paraffin embedded. For physiological and molecular studies, the vagina was cut open longitudinally and the proximal vagina (upper $2 / 3$ ) was dissected from the distal vagina as outlined by Basha et al. (18). Proximal vaginal segments were either snap frozen in liquid nitrogen and stored at $-80^{\circ} \mathrm{C}$ or placed in ice-cold MOPS-buffered physiological salt solution (PSS) for same-day physiological studies. The PSS solution contained (in mM) 140 $\mathrm{NaCl}, 4.7 \mathrm{KCl}, 1.2 \mathrm{MgSO}_{4}, 1.6 \mathrm{CaCl}_{2}, 1.2 \mathrm{Na}_{2} \mathrm{HPO}_{4}, 2.03$-(N-morpholino) propanesulfonic acid, 5.0 D-glucose and 0.02 $\mathrm{Na}_{2}$-EDTA. 
Histology

Cross sections of 5- $\mu \mathrm{m}$ thickness were taken from the proximal end of the paraffin embedded vaginal tube ( $\mathrm{n}=3$ animals/group). Images of Masson's trichrome stained (MTS) sections were visualized with an Olympus BX60 microscope (Oylmpus America, Melville, NY) and captured with an Olympus DP70 camera (Olympus, America, Melville, NY).

\section{Reverse Transcriptase and Polymerase Chain Reaction}

RNA was extracted from frozen vaginal tissue segments ( $\mathrm{n}=5$ animals/group) and quantified as previously described (18). $1.0 \mu \mathrm{g}$ of RNA was reverse transcribed with oligo (dT) primer (Promega, Madison, WI) and Moloney murine leukemia virus reverse transcriptase (Invitrogen, Carlsbad, CA) at $37^{\circ} \mathrm{C}$ for 60 minutes. The reaction was stopped by heating to $90^{\circ} \mathrm{C}$. PCR was performed with $1 \mu \mathrm{l}$ of cDNA in $49 \mu \mathrm{l}$ reaction mixture containing the following: upstream and downstream primers, 10× PCR Buffer (Applied Biosystems, Foster City, CA), dNTP (Roche Applied Science, Germany) and Taq polymerase (Perkin-Elmer, Foster City, CA). The 5' to 3' sequences of primers were as follows:

SM-A/SM-B: CCA CAA GGG CAA GAA AGA CAG C (upstream); TCC GGC GAG CAG GTA GAA GA (downstream)

SM1/SM2: AGC AGG CAG AGA AAG GAA ACA CCA (upstream); GAA GTC TGA GTC CCG AGC GTC CAT (downstream)

\section{Western Blot Analysis}

Protein was extracted from $50-100 \mathrm{mg}$ of frozen proximal vaginal segments ( $\mathrm{n}=5$ animals/ group) and quantified as previously described (18). Samples were separated by SDS-PAGE and protein was transferred to Immobilon-P membranes (Millipore, Bedford,

Massachusetts). Membranes were blocked with 5\% non-fat milk for one hour in 0.1\% PBST prior to antibody incubations. Membranes were washed 3 times for 5 minutes in $0.1 \%$ PBST following each antibody incubation. For analysis of MHC, 5 ug of protein was separated using a 7.5\% gel and the membrane was incubated for one hour in a 1:50,000 dilution of a polyclonal MHC antibody generated in rabbits against bovine aorta (gift of Dr. R. Adelstein, $\mathrm{NIH}$, Bethesda, MD), followed by a one hour incubation in a 1:3,000 dilution of secondary antibody (NA934V, GE Healthcare, Piscataway, NJ). As an internal control, the membrane was incubated for one hour in a 1:5,000 dilution of $\beta$-actin primary antibody (A5316, Sigma, St. Louis, MO), followed by a one hour incubation in a 1:3,000 dilution of secondary antibody (NA931V, GE Healthcare, Piscataway, NJ). For analysis of caldesmon, $10 \mu \mathrm{g}$ of protein was separated using a 10\% gel and the membrane was incubated in a 1:10,0000 dilution of primary antibody (C0297, Sigma, Saint Louis, MO) for 2 hours, followed by a one hour incubation in a 1:3,000 dilution of secondary antibody (NA931V, GE Healthcare, Piscataway, NJ). As an internal control for caldesmon, the membrane was incubated for one hour in a 1:100, 000 dilution of a-actin primary antibody (A2547, Sigma, Saint Louis, MO), followed by a one hour incubation in a 1:5,000 dilution of secondary antibody (NA931V, GE Healthcare, Piscataway, NJ). MHC, caldesmon, $\beta$-actin, and $\alpha$-actin were detected using an enhanced chemiluminescence kit (RPN2109, GE Healthcare, Piscataway, NJ). Resultant autoradiograms were analyzed by scanning densitometry with quantitation software (Quantity One, Bio-Rad, Hercules, CA).

\section{Coomassie staining for visualization of carboxyl terminal isoforms (SM1 and SM2) of MHC}

SM1 and SM2 isoforms of MHC were separated electrophoretically and then visualized by Coomassie staining. Briefly, up to $100 \mu \mathrm{g}$ of protein was separated overnight by SDS-PAGE using a large format $(16 \times 16 \mathrm{~cm}) 7.5 \%$ gel. SM1/SM2 bands visualized by Coomassie blue 
staining were then analyzed by scanning densitometry with quantitation software (Quantity One, Bio-Rad, Hercules, CA).

\section{Isometric Force Measurements}

Longitudinal strips of proximal vagina measuring $\sim 1.5 \mathrm{~mm} \times 6 \mathrm{~mm}$ were cut from the proximal vagina ( $\mathrm{n}=5$; each strip obtained from a different animal from each group). Each strip was mounted between a force transducer (Grass model FT.03) and a glass rod and immersed in water-jacketed organ baths containing PSS $\left(37^{\circ} \mathrm{C}\right.$, aerated with $\left.100 \% \mathrm{O}_{2}\right)$. Strips were equilibrated for 90 minutes, during which time they were stretched to optimal length of contraction $\left(\mathrm{L}_{\mathrm{o}}\right)$ as previously described (18). Following measurement of peak force to $110 \mathrm{mM} \mathrm{KCl}$ (equimolar substitution for $\mathrm{NaCl}$ ), strips were placed in Histochoice fixative and embedded in paraffin for determination of cross-sectional area of muscle and tissue as follows. Cross-sections ( 5 um thickness) were obtained from the center of each longitudinal strip. Images of MTS cross-sections were viewed and captured as described above and analyzed for muscle cross-sectional area and total cross sectional area using Image $\mathbf{J}$ software. The amplitude of each contraction at peak force was normalized to crosssectional area of muscle. The \% vaginal muscularis was calculated as the ratio of cross sectional area muscle/ cross sectional area strip.

\section{Measurement of $\mathrm{V}_{\max }$}

Longitudinal strips measuring $\sim 1.5 \mathrm{~mm} \times 6 \mathrm{~mm}$ were cut from the proximal vagina of ovariectomized rats $(n=3$; each strip was obtained from a different animal). Each strip was mounted on one end to a micrometer, via a plastic clip, for control of muscle length. The other end was attached to an aluminum foil tube connected to a servo-lever (Model 300H, Cambridge Technology) interfaced to a Linux operating system-based computer. The preparation was immersed in a water-jacketed muscle chamber containing PSS at $37{ }^{\circ} \mathrm{C}$ and aerated with $100 \% \mathrm{O}_{2} . \mathrm{V}_{\max }$ was calculated at the point of peak force generation in response to $110 \mathrm{mM} \mathrm{KCl} \mathrm{stimulation} \mathrm{of} \mathrm{tissue} \mathrm{strips} \mathrm{as} \mathrm{previously} \mathrm{described} \mathrm{(18).} \mathrm{Briefly,}$ strips were stimulated with $110 \mathrm{mM} \mathrm{KCl}$ and subjected to a series of isotonic quick releases to afterloads equaling 5,10,15 and $20 \%$ of the force at the time of release. Isotonic shortening velocity at each afterload was determined by the change in length versus time $100 \mathrm{~ms}$ after release. The velocities of shortening calculated at these afterloads were used to extrapolate velocity at zero load for estimation of $\mathrm{V}_{\max }$.

\section{Statistical analysis}

All data are expressed as means \pm S.D. Statistical analysis was performed using Graph Pad Prism software, ver 5 (GraphPad Software Inc., San Diego, CA). Measurements were analyzed using one-way ANOVA followed by post hoc analysis (Tukey's) when results of the one-way ANOVA indicated significance $(a=0.05)$.

\section{Results}

Ovariectomized rats exhibited a significant increase in body weight, decrease in uterine weight, and decrease in serum 17- $\beta$ estradiol concentrations as compared to sham animals. One week of estrogen replacement 14 days following ovariectomy resulted in uterine weights that were similar to sham animals, and partially returned body weight to normal. Serum 17- $\beta$ estradiol concentrations of estrogen-replaced rats were not significantly different than sham animals (Table 1), indicating that our protocol resulted in physiological doses of estrogen. Qualitative assessment of MTS cross-sections of the proximal vagina verified that our animal model of menopause resulted in vaginal atrophy, with an overall thinning of the proximal vaginal wall. Estrogen replacement reversed this atrophy and wall thickness appeared similar to sham animals (Figure 1). 
No significant differences were detected in the amount of MHC protein, or the ratio of amino-terminal isoforms of MHC (SM-A and SM-B) transcript expression within the proximal vagina of ovariectomized rats as compared to sham animals (data not shown). In contrast, analysis of mRNA transcript and protein expression for carboxyl terminal MHC isoforms demonstrated that the \%SM1, quantified as [SM1/ (SM1 + SM2)], was decreased in ovariectomized rats. Systemic administration of estrogen reversed the decrease in \%SM1 (Figure 2 and Figure 3). Ovariectomy also had a significant effect on the expression of the thin filament associated protein, $h$-caldesmon with a two-fold reduction in $h$-caldesmon: $a$ actin ratio, an effect reversed by estrogen replacement (Figure 4). The antibody utilized for analysis of protein expression of caldesmon detected both $h$ - and $l$-caldesmon isoforms. Bands for the $l$-isoform were detected with longer film exposures. No significant differences were detected in $l$-isoform expression amongst groups.

Morphometric analysis of the tissue strips used for physiological studies indicated that the total cross sectional area of the tissue strips, muscle cross-sectional area of the tissue strips, and percentage of smooth muscle within the proximal vagina were not significantly different amongst experimental groups (Table 2). Ovariectomy resulted in a significant reduction in peak force of $110 \mathrm{mM} \mathrm{KCL}$ induced contractions (Figure 5). A significant reduction in peak force was detected when the amplitude of contraction was expressed as raw peak force $(\mathrm{P}<$ $0.05)$, peak force/cross sectional area of the strips $(\mathrm{P}<0.01)$, and peak force normalized to cross sectional area of muscle $(\mathrm{P}<0.001)$. Estrogen replacement resulted in a return of these values to that of strips obtained from sham operated animals (Figure 6). Ovariectomy had no effect on myosin ATPase activity as estimated by $\mathrm{V}_{\max }$ of the proximal vaginal strips. Values obtained using muscle strips from ovariectomized animals were similar $(0.10 \pm .01$ muscle lengths/sec) to our previous report of $\mathrm{V}_{\max }$ of the proximal vagina from control rats $(0.11 \pm 0.04$ muscle lengths/sec) using identical procedures (18).

\section{Discussion}

The results of this study demonstrate an estrogen dependence of contractile protein expression and functional characteristics of the rodent proximal vaginal muscularis. We report a significant effect of ovariectomy on carboxyl-terminal MHC isoform and $h$ caldesmon expression within the vagina. Additionally, physiological studies indicated a decreased force of contraction of the vaginal muscularis of ovariectomized rats. Systemic administration of physiological doses of $17-\beta$ estradiol reversed molecular and functional changes. These findings suggest that menopausal vaginal atrophy includes both molecular and functional changes of vaginal smooth muscle.

We report that ovariectomy resulted in thinning of the vaginal wall (Figure 1) with no detectable differences in MHC protein expression and a-actin protein expression across treatments. Estimation of cross sectional area of muscle and \% vaginal muscularis indicated a slight reduction of smooth muscle within tissue strips obtained from the proximal vagina of ovariectomized animals although these changes were not significant (Table 2). Taken together these findings suggest that vaginal atrophy induced by decreases in ovarian hormones includes a decrease in the vaginal muscularis that is proportional to decreases in other layers of the vaginal wall resulting in little change of the calculated percentage of the wall composed of smooth muscle. Our results are In support of previous studies of the rabbit 4 and 12 weeks following ovariectomy $(4 ; 8)$ and 4 week ovariectomized rodents (51). Our results are also in support of findings obtained with human tissue as it has been shown that MHC mRNA transcript expression was not altered within the vaginal muscularis of postmenopausal compared to premenopausal women (45). On the other hand, MHC isoform expression of the vaginal muscularis was altered by estrogen status in our study. and our findings of a decrease in the \%SM1 following ovariectomy (Figure 2 and Figure 3) with no 
effect on N-terminal MHC isoform expression (SMA, SMB) corroborate the results obtained in studies utilizing smooth muscle from uterus (22;52), aorta (25), and bladder (23). Alterations in smooth muscle carboxyl-terminal isoform expression have also been reported in animal models of bladder outlet obstruction $(53 ; 54)$, diabetes (53), atherosclerosis (54) and hypertension (55). Despite reports of changes in carboxyl terminal isoform expression in both physiological and pathological conditions, the physiological relevance of the relative expression of SM1/SM2 isoforms is unresolved (16;26-31;56). Some (26;27), but not all $(16 ; 28 ; 29)$, studies have demonstrated a positive correlation between the SM1 isoform and unloaded shortening velocity. Results are also conflicting regarding a role of carboxyl terminal isoforms on filament assembly (29;30;57). A recent study using SM2 knockout mice shows SM (+/-) male mice with relatively high ratio of SM1/SM2 are predisposed to develop urinary tract obstruction and hypercontractility of bladder smooth muscle upon aging (56). Thus, there is evidence that suggests a relationship between changes in MHC isoform expression and smooth muscle function in this study.

Consistent with a previous report showing a reduction of $h$-caldesmon within the detrusor muscle of 3 week ovariectomized rabbits (32), we detected a 2 -fold decrease in the $h$ caldesmon : $a$-actin ratio within the proximal vagina of ovariectomized animals; an effect reversed by estrogen replacement. However, our finding that 1-week estrogen replacement restored $h$-caldesmon expression (Figure 4 ) is at odds with Lin et al. (32) who reported that 1 -week estrogen replacement reduced $h$-caldesmon expression below that of control animals. This discrepancy may due to species differences, differences between the vaginal muscularis and detrusor muscle, or differences in dose of estrogen. The estrogen replacement protocol utilized by Lin et al. (58) resulted in estradiol levels $>5$-fold higher than control animals compared to physiological doses in our present study. Ovarian hormone regulation of caldesmon expression has also been demonstrated in uterine smooth muscle with an upregulation of myometrial $h$-caldesmon expression reported late in gestation in both animal $(35 ; 59)$ and humans (36-38). As $h$-caldesmon has been shown to inhibit myosin ATPase activity (see (60) for review), upregulation of this protein has been postulated to be a molecular mechanism to maintain quiescence of the myometrium during gestation.

Alterations in caldesmon expression within the vaginal muscularis of women with POP have been reported although results are conflicting, with both an increase in $h$-caldesmon mRNA transcript and protein expression $(44 ; 45)$ and a decrease in $h$-caldesmon mRNA transcript expression (42) detected within the vaginal muscularis. An increase in $h$-caldesmon expression has also been reported within the uterosacral ligament of women with POP (61). Given the results reported herein, it is likely that the discrepancy is related to the difficulty in controlling for hormonal status, age, and parity in human studies. Indeed, Bortolini et al. (45) demonstrated that caldesmon mRNA transcript expression is downregulated in vaginal cuff biopsies obtained from healthy postmenopausal women compared to healthy premenopausal women. Our result of decreased vaginal $h$-caldesmon protein expression in ovariectomized rats, and reversal of this down regulation within the vaginal muscularis following estrogen replacement, supports and expands upon this finding by demonstrating estrogenic regulation of $h$-caldesmon protein expression. Upregulation of $h$-caldesmon mRNA transcript expression has been reported in vaginal cuff biopsies obtained from postmenopausal POP patients compared to postmenopausal control subjects (45), with no differences detected between premenopausal POP patients and control subjects. This study sheds light on the finding of Northington et al. (40) who failed to detect differences in $\mathrm{KCl}$ induced contractile force (force/ $\mathrm{mm}^{2}$ muscle) of the vaginal muscularis of premenopausal POP and control subjects. Taken together, these findings highlight the need to control for hormonal status when conducting studies of vaginal changes in patients with POP and suggest that the pathophysiology of POP may be distinct between premenopausal and postmenopausal women. 
It remains to be determined if changes in $h$-caldesmon expression within the vagina is a cause or a consequence of prolapse. It is unclear if increased $h$-caldesmon expression may be a compensatory response to POP in postmenopausal women or representative of a decompensated state of the vaginal muscularis. There is evidence that mechanical stretch may regulate $h$-caldesmon expression $(53 ; 62)$ and phosphorylation of caldesmon, which modulates caldesmon's inhibitory effect on myosin ATPase activity $(38 ; 63)$. Therefore, future studies determining the effects of stretch on the vaginal muscularis in intact and ovarian hormone deprived animals may help to further elucidate the relationship between prolapse, menopause, $h$ - caldesmon, and $h$-caldesmon phosphorylation.

It has been reported that ovariectomy decreases contractility of detrusor smooth muscle (58) and the distal rat vagina (9) with supraphysiological replacement of estrogen increasing force of contraction of these tissues. In light of regional differences between the proximal and distal vagina, we focused our investigation on the proximal vagina to facilitate comparison of results obtained with human biopsies obtained from the vaginal cuff. We report a decreased peak force, peak force/cross-sectional area of tissue strip, and peak force/ cross-sectional muscle area of the proximal vagina of ovariectomized rats in response to $\mathrm{KCl}$ stimulation, with physiological estrogen replacement returning force of contraction to sham values (Figure 5 and 6). Our finding of decreased force normalized to cross sectional area of muscle demonstrate that molecular changes within the smooth muscle layer contribute to compromised contractility of the proximal vagina of ovariectomized animals. However, as our current report describes changes in more than one contractile protein, it is difficult to identify the impact each molecular change has upon vaginal smooth muscle function. Nevertheless, our findings provide evidence that menopause may be associated with compromised contractility of the proximal vaginal muscularis due both to a reduction in the smooth muscle layer and to changes in its molecular composition. As animal models of female sexual arousal have demonstrated contraction of the proximal vagina in response to pelvic nerve stimulation $(64 ; 65)$, results of this study indicate that menopause induced changes in the proximal vaginal muscularis may contribute to increased female sexual dysfunction with age. Ongoing studies in our laboratory are investigating the effect of ovarian hormones on sympathetic and parasympathetic agonist induced force of the rodent vaginal muscularis.

There are limitations to our study. Vaginal tissue from all sham-operated animals was collected one week following vehicle replacement in order to be consistent with the time point of tissue collection from ovariectomized and estrogen replaced animals. We therefore did not control for stage of estrus cycle in sham animals, which may have contributed to variability in our data from the control group.

In summary, our results demonstrate an estrogen dependence of contractile protein expression and contractility within the rodent proximal vaginal muscularis. Our novel finding of estrogenic regulation of $h$-caldesmon within the vaginal muscularis is of particular clinical significance as altered $h$-caldesmon expression has been reported within the vaginal muscularis of patients with POP $(42 ; 44)$. Future studies should determine the efficacy of vaginal estrogen replacement on reversing ovariectomy or age-dependent changes within vaginal smooth muscle in light of recommendations for local delivery of estrogens for vulvovaginal atrophy with menopause and dyspareunia (66;67). In addition, as previous studies have demonstrated androgen receptor expression within the vaginal muscularis (5), and changes in vaginal muscularis structure following androgen replacement (51), further research determining androgenic regulation of vaginal smooth muscle is warranted. 


\section{Acknowledgments}

This study was supported by National Institute of Diabetes and Digestive and Kidney Diseases Grants P50 DK 52620, DK 69898 (Samuel K. Chacko) to the University of Pennsylvania, DK 57252 and DK 85734 to Robert S. Moreland and an American Urological Association Research Scholar Award to Maureen Basha.

\section{Reference List}

1. Yoon HN, Chung WS, Park YY, Shim BS, Han WS, Kwon SW. Effects of estrogen on nitric oxide synthase and histological composition in the rabbit clitoris and vagina. Int J Impot Res. 2001 Aug; 13(4):205-211. [PubMed: 11494077]

2. Berger L, El-Alfy M, Martel C, Labrie F. Effects of dehydroepiandrosterone, Premarin and Acolbifene on histomorphology and sex steroid receptors in the rat vagina. J Steroid Biochem Mol Biol. 2005 Jul; 96(2):201-215. [PubMed: 15979306]

3. Berman JR, McCarthy MM, Kyprianou N. Effect of estrogen withdrawal on nitric oxide synthase expression and apoptosis in the rat vagina. Urology. 1998 Apr; 51(4):650-656. [PubMed: 9586624]

4. Higgins EW, Rao A, Baumann SS, James RL, Kuehl TJ, Muir TW, Pierce LM. Effect of estrogen replacement on the histologic response to polypropylene mesh implanted in the rabbit vagina model. Am J Obstet Gynecol. 2009 Nov; 201(5):505-509. [PubMed: 19683695]

5. Pessina MA, Hoyt RF Jr, Goldstein I, Traish AM. Differential regulation of the expression of estrogen, progesterone, and androgen receptors by sex steroid hormones in the vagina: immunohistochemical studies. J Sex Med. 2006 Sep; 3(5):804-814. [PubMed: 16942525]

6. Ting AY, Blacklock AD, Smith PG. Estrogen regulates vaginal sensory and autonomic nerve density in the rat. Biol Reprod. 2004 Oct; 71(4):1397-1404. [PubMed: 15189832]

7. Park K, Ahn K, Lee S, Ryu S, Park Y, Azadzoi KM. Decreased circulating levels of estrogen alter vaginal and clitoral blood flow and structure in the rabbit. Int J Impot Res. 2001 Apr; 13(2):116124. [PubMed: 11426351]

8. Kim NN, Min K, Pessina MA, Munarriz R, Goldstein I, Traish AM. Effects of ovariectomy and steroid hormones on vaginal smooth muscle contractility. Int J Impot Res. 2004 Feb; 16(1):43-50. [PubMed: 14963470]

9. Onol FF, Ercan F, Tarcan T. The effect of ovariectomy on rat vaginal tissue contractility and histomorphology. J Sex Med. 2006 Mar; 3(2):233-241. [PubMed: 16490016]

10. Moalli PA, Debes KM, Meyn LA, Howden NS, Abramowitch SD. Hormones restore biomechanical properties of the vagina and supportive tissues after surgical menopause in young rats. Am J Obstet Gynecol. 2008 Aug; 199(2):161-168. [PubMed: 18395691]

11. Babij P, Kelly C, Periasamy M. Characterization of a mammalian smooth muscle myosin heavychain gene: complete nucleotide and protein coding sequence and analysis of the 5 ' end of the gene. Proc Natl Acad Sci U S A. 1991 Dec 1; 88(23):10676-10680. [PubMed: 1961735]

12. Babij P, Periasamy M. Myosin heavy chain isoform diversity in smooth muscle is produced by differential RNA processing. J Mol Biol. 1989 Dec 5; 210(3):673-679. [PubMed: 2614841]

13. White S, Martin AF, Periasamy M. Identification of a novel smooth muscle myosin heavy chain cDNA: isoform diversity in the S1 head region. Am J Physiol. 1993 May; 264(5 Pt 1):C1252C1258. [PubMed: 7684561]

14. Hamada Y, Yanagisawa M, Katsuragawa Y, Coleman JR, Nagata S, Matsuda G, Masaki T. Distinct vascular and intestinal smooth muscle myosin heavy chain mRNAs are encoded by a single-copy gene in the chicken. Biochem Biophys Res Commun. 1990 Jul 16; 170(1):53-58. [PubMed: 2372298]

15. DiSanto ME, Cox RH, Wang Z, Chacko S. NH2-terminal-inserted myosin II heavy chain is expressed in smooth muscle of small muscular arteries. Am J Physiol. 1997 May; 272(5 Pt 1):C1532-C1542. [PubMed: 9176144]

16. Sherwood JJ, Eddinger TJ. Shortening velocity and myosin heavy- and light-chain isoform mRNA in rabbit arterial smooth muscle cells. Am J Physiol Cell Physiol. 2002 May; 282(5):C1093C1102. [PubMed: 11940525] 
17. Eddinger TJ, Meer DP. Single rabbit stomach smooth muscle cell myosin heavy chain SMB expression and shortening velocity. Am J Physiol Cell Physiol. 2001 Feb; 280(2):C309-C316. [PubMed: 11208526]

18. Basha M, Chang S, Smolock EM, Moreland RS, Wein AJ, Chacko S. Regional differences in myosin heavy chain isoform expression and maximal shortening velocity of the rat vaginal wall smooth muscle. Am J Physiol Regul Integr Comp Physiol. 2006 Oct; 291(4):R1076-R1084. [PubMed: 16690774]

19. Kelley CA, Takahashi M, Yu JH, Adelstein RS. An insert of seven amino acids confers functional differences between smooth muscle myosins from the intestines and vasculature. J Biol Chem. 1993 Jun 15; 268(17):12848-12854. [PubMed: 8509418]

20. Rovner AS, Thompson MM, Murphy RA. Two different heavy chains are found in smooth muscle myosin. Am J Physiol. 1986 Jun; 250(6 Pt 1):C861-C870. [PubMed: 3013015]

21. Nagai R, Kuro-o M, Babij P, Periasamy M. Identification of two types of smooth muscle myosin heavy chain isoforms by cDNA cloning and immunoblot analysis. J Biol Chem. 1989 Jun 15; 264(17):9734-9737. [PubMed: 2722872]

22. Capriani A, Chiavegato A, Franch R, Azzarello G, Vinante O, Sartore S. Oestrogen-dependent expression of the SM2 smooth muscle-type myosin isoform in rabbit myometrium. J Muscle Res Cell Motil. 1997 Aug; 18(4):413-427. [PubMed: 9276335]

23. Sanchez-Ortiz RF, Wang Z, Menon C, DiSanto ME, Wein AJ, Chacko S. Estrogen modulates the expression of myosin heavy chain in detrusor smooth muscle. Am J Physiol Cell Physiol. 2001 Mar; 280(3):C433-C440. [PubMed: 11171561]

24. Ishibashi K, Evans A, Shingu T, Bian K, Bukoski RD. Differential expression and effect of 1,25dihydroxyvitamin D3 on myosin in arterial tree of rats. Am J Physiol. 1995 Aug; 269(2 Pt 1):C443-C450. [PubMed: 7653526]

25. Paul RJ, Bowman PS, Johnson J, Martin AF. Effects of sex and estrogen on myosin COOHterminal isoforms and contractility in rat aorta. Am J Physiol Regul Integr Comp Physiol. 2007 Feb; 292(2):R751-R757. [PubMed: 16917024]

26. Sparrow MP, Mohammad MA, Arner A, Hellstrand P, Ruegg JC. Myosin composition and functional properties of smooth muscle from the uterus of pregnant and non-pregnant rats. Pflugers Arch. 1988 Oct; 412(6):624-633. [PubMed: 3211713]

27. Morano I, Koehlen S, Haase H, Erb G, Baltas LG, Rimbach S, Wallwiener D, Bastert G. Alternative splicing and cycling kinetics of myosin change during hypertrophy of human smooth muscle cells. J Cell Biochem. 1997 Feb; 64(2):171-181. [PubMed: 9027578]

28. Kelley CA, Sellers JR, Goldsmith PK, Adelstein RS. Smooth muscle myosin is composed of homodimeric heavy chains. J Biol Chem. 1992 Feb 5; 267(4):2127-2130. [PubMed: 1733920]

29. Rovner AS, Fagnant PM, Lowey S, Trybus KM. The carboxyl-terminal isoforms of smooth muscle myosin heavy chain determine thick filament assembly properties. J Cell Biol. 2002 Jan 7; 156(1): 113-123. [PubMed: 11781338]

30. Ikebe M, Hewett TE, Martin AF, Chen M, Hartshorne DJ. Cleavage of a smooth muscle myosin heavy chain near its $\mathrm{C}$ terminus by alpha-chymotrypsin. Effect on the properties of myosin. J Biol Chem. 1991 Apr 15; 266(11):7030-7036. [PubMed: 1826682]

31. Martin AF, Bhatti S, Pyne-Geithman GJ, Farjah M, Manaves V, Walker L, Franks R, Strauch AR, Paul RJ. Expression and function of COOH-terminal myosin heavy chain isoforms in mouse smooth muscle. Am J Physiol Cell Physiol. 2007 Jul; 293(1):C238-C245. [PubMed: 17392380]

32. Lin AD, Levin RM, Kogan BA, Whitbeck C, Leggett RE, Kearns C, Mannikarottu A. Alteration of contractile and regulatory proteins in estrogen-induced hypertrophy of female rabbit bladder. Urology. 2006 Nov; 68(5):1139-1143. [PubMed: 17113912]

33. Owada MK, Hakura A, Iida K, Yahara I, Sobue K, Kakiuchi S. Occurrence of caldesmon (a calmodulin-binding protein) in cultured cells: comparison of normal and transformed cells. Proc Natl Acad Sci U S A. 1984 May; 81(10):3133-3137. [PubMed: 6328499]

34. Tanaka T, Sobue K, Owada MK, Hakura A. Linear relationship between diphosphorylation of 20 $\mathrm{kDa}$ light chain of gizzard myosin and the actin-activated myosin ATPase activity. Biochem Biophys Res Commun. 1985 Sep 16; 131(2):987-993. [PubMed: 2932111] 
35. Riley M, Wu X, Baker PN, Taggart MJ. Gestational-dependent changes in the expression of signal transduction and contractile filament-associated proteins in mouse myometrium. J Soc Gynecol Investig. 2005 Jul; 12(5):e33-e43.

36. Riley M, Baker PN, Tribe RM, Taggart MJ. Expression of scaffolding, signalling and contractilefilament proteins in human myometria: effects of pregnancy and labour. J Cell Mol Med. 2005 Jan; 9(1):122-134. [PubMed: 15784170]

37. Word RA, Stull JT, Casey ML, Kamm KE. Contractile elements and myosin light chain phosphorylation in myometrial tissue from nonpregnant and pregnant women. J Clin Invest. 1993 Jul; 92(1):29-37. [PubMed: 8392087]

38. Li Y, Reznichenko M, Tribe RM, Hess PE, Taggart M, Kim H, DeGnore JP, Gangopadhyay S, Morgan KG. Stretch activates human myometrium via ERK, caldesmon and focal adhesion signaling. PLoS One. 2009; 4(10):e7489. [PubMed: 19834610]

39. DeLancey JO, Starr RA. Histology of the connection between the vagina and levator ani muscles. Implications for urinary tract function. J Reprod Med. 1990 Aug; 35(8):765-771. [PubMed: 2213737]

40. Northington GM, Basha M, Arya LA, Wein AJ, Chacko S. Contractile response of human anterior vaginal muscularis in women with and without pelvic organ prolapse. Reprod Sci. 2011 Mar; 18(3):296-303. [PubMed: 21193802]

41. Boreham MK, Wai CY, Miller RT, Schaffer JI, Word RA. Morphometric analysis of smooth muscle in the anterior vaginal wall of women with pelvic organ prolapse. Am J Obstet Gynecol. 2002 Jul; 187(1):56-63. [PubMed: 12114889]

42. Takacs P, Gualtieri M, Nassiri M, Candiotti K, Fornoni A, Medina CA. Caldesmon expression is decreased in women with anterior vaginal wall prolapse: a pilot study. Int Urogynecol J Pelvic Floor Dysfunct. 2009 Aug; 20(8):985-990. [PubMed: 19582387]

43. Badiou W, Granier G, Bousquet PJ, Monrozies X, Mares P, de TR. Comparative histological analysis of anterior vaginal wall in women with pelvic organ prolapse or control subjects. A pilot study. Int Urogynecol J Pelvic Floor Dysfunct. 2008 May; 19(5):723-729. [PubMed: 18183343]

44. Boreham MK, Miller RT, Schaffer JI, Word RA. Smooth muscle myosin heavy chain and caldesmon expression in the anterior vaginal wall of women with and without pelvic organ prolapse. Am J Obstet Gynecol. 2001 Oct; 185(4):944-952. [PubMed: 11641683]

45. Bortolini MA, Shynlova O, Drutz HP, Castro RA, Girao MJ, Lye S, Alarab M. Expression of genes encoding smooth muscle contractile proteins in vaginal tissue of women with and without pelvic organ prolapse. Neurourol Urodyn. 2012 Jan; 31(1):109-114. [PubMed: 22038928]

46. Basha M, Labelle EF, Northington GM, Wang T, Wein AJ, Chacko S. Functional significance of muscarinic receptor expression within the proximal and distal rat vagina. Am J Physiol Regul Integr Comp Physiol. 2009 Nov; 297(5):R1486-R1493. [PubMed: 19741053]

47. Min K, O'Connell L, Munarriz R, Huang YH, Choi S, Kim N, Goldstein I, Traish A. Experimental models for the investigation of female sexual function and dysfunction. Int J Impot Res. 2001 Jun; 13(3):151-156. [PubMed: 11525313]

48. Giraldi A, Alm P, Werkstrom V, Myllymaki L, Wagner G, Andersson KE. Morphological and functional characterization of a rat vaginal smooth muscle sphincter. Int J Impot Res. 2002 Aug; 14(4):271-282. [PubMed: 12152117]

49. Kim SW, Jeong SJ, Munarriz R, Kim NN, Goldstein I, Traish AM. Role of the nitric oxide-cyclic GMP pathway in regulation of vaginal blood flow. Int J Impot Res. 2003 Oct; 15(5):355-361. [PubMed: 14562137]

50. Oh SJ, Hong SK, Kim SW, Paick JS. Histological and functional aspects of different regions of the rabbit vagina. Int J Impot Res. 2003 Apr; 15(2):142-150. [PubMed: 12789395]

51. Pessina MA, Hoyt RF Jr, Goldstein I, Traish AM. Differential effects of estradiol, progesterone, and testosterone on vaginal structural integrity. Endocrinology. 2006 Jan; 147(1):61-63. [PubMed: 16210369]

52. Hewett TE, Martin AF, Paul RJ. Correlations between myosin heavy chain isoforms and mechanical parameters in rat myometrium. J Physiol. 1993 Jan.460:351-364. [PubMed: 8487199] 
53. Zhang EY, Stein R, Chang S, Zheng Y, Zderic SA, Wein AJ, Chacko S. Smooth muscle hypertrophy following partial bladder outlet obstruction is associated with overexpression of nonmuscle caldesmon. Am J Pathol. 2004 Feb; 164(2):601-612. [PubMed: 14742265]

54. Itoh S, Umemoto S, Hiromoto M, Toma Y, Tomochika Y, Aoyagi S, Tanaka M, Fujii T, Matsuzaki $\mathrm{M}$. Importance of NAD $(\mathrm{P}) \mathrm{H}$ oxidase-mediated oxidative stress and contractile type smooth muscle myosin heavy chain SM2 at the early stage of atherosclerosis. Circulation. 2002 May 14; 105(19): 2288-2295. [PubMed: 12010912]

55. Kubo M, Umemoto S, Fujii K, Itoh S, Tanaka M, Kawahara S, Matsuzaki M. Effects of angiotensin II type 1 receptor antagonist on smooth muscle cell phenotype in intramyocardial arteries from spontaneously hypertensive rats. Hypertens Res. 2004 Sep; 27(9):685-693. [PubMed: 15750263]

56. Chi M, Zhou Y, Sopariwala D, Periasamy M. SM2(+/-) male mice are predisposed to develop urinary tract obstruction and hyper contractility of the bladder smooth muscle upon ageing. $\mathrm{J}$ Smooth Muscle Res. 2011; 47(3-4):67-78. [PubMed: 21979406]

57. Hodge TP, Cross R, Kendrick-Jones J. Role of the COOH-terminal nonhelical tailpiece in the assembly of a vertebrate nonmuscle myosin rod. J Cell Biol. 1992 Sep; 118(5):1085-1095. [PubMed: 1512291]

58. Lin AD, Levin R, Kogan B, Whitbeck C, Chichester P, Sokol R, Mannikarottu A. Estrogen induced functional hypertrophy and increased force generation of the female rabbit bladder. Neurourol Urodyn. 2006; 25(5):473-479. [PubMed: 16688710]

59. Li Y, Je HD, Malek S, Morgan KG. ERK1/2-mediated phosphorylation of myometrial caldesmon during pregnancy and labor. Am J Physiol Regul Integr Comp Physiol. 2003 Jan; 284(1):R192R199. [PubMed: 12388473]

60. Lin JJ, Li Y, Eppinga RD, Wang Q, Jin JP. Chapter 1: roles of caldesmon in cell motility and actin cytoskeleton remodeling. Int Rev Cell Mol Biol. 2009; 274:1-68. [PubMed: 19349035]

61. Takacs P, Gualtieri M, Nassiri M, Candiotti K, Fornoni A, Medina CA. Differential expression of smooth muscle regulatory proteins in the uterosacral ligaments of women with uterine prolapse. Am J Obstet Gynecol. 2010 Jun; 202(6):620-625. [PubMed: 20413103]

62. Yang L, He DL, Wang S, Cheng HP, Wang XY. Effect of long-term partial bladder outlet obstruction on caldesmon isoforms and their correlation with contractile function. Acta Pharmacol Sin. 2008 May; 29(5):600-605. [PubMed: 18430369]

63. Li Y, Gallant C, Malek S, Morgan KG. Focal adhesion signaling is required for myometrial ERK activation and contractile phenotype switch before labor. J Cell Biochem. 2007 Jan 1; 100(1):129_ 140. [PubMed: 16888778]

64. Min K, Munarriz R, Berman J, Kim NN, Goldstein I, Traish AM, Stankovic MR. Hemodynamic evaluation of the female sexual arousal response in an animal model. J Sex Marital Ther. 2001 Oct; 27(5):557-565. [PubMed: 11554219]

65. Giuliano F, Allard J, Compagnie S, Alexandre L, Droupy S, Bernabe J. Vaginal physiological changes in a model of sexual arousal in anesthetized rats. Am J Physiol Regul Integr Comp Physiol. 2001 Jul; 281(1):R140-R149. [PubMed: 11404287]

66. Estrogen and progestogen use in postmenopausal women: 2010 position statement of The North American Menopause Society. Menopause. 2010 Mar; 17(2):242-255. [PubMed: 20154637]

67. Krychman ML. Vaginal estrogens for the treatment of dyspareunia. J Sex Med. 2011 Mar; 8(3): 666-674. [PubMed: 21091878] 


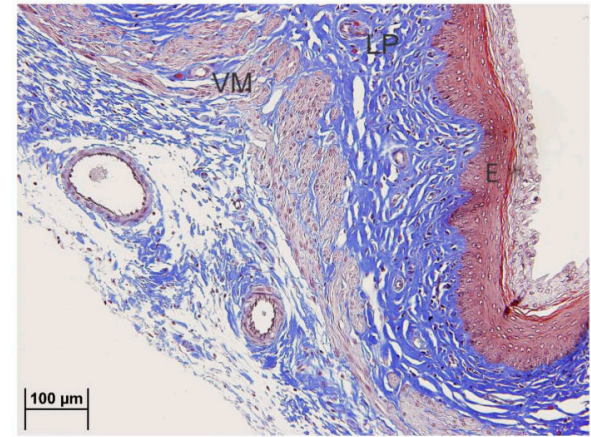

Sham-Ovariectomized

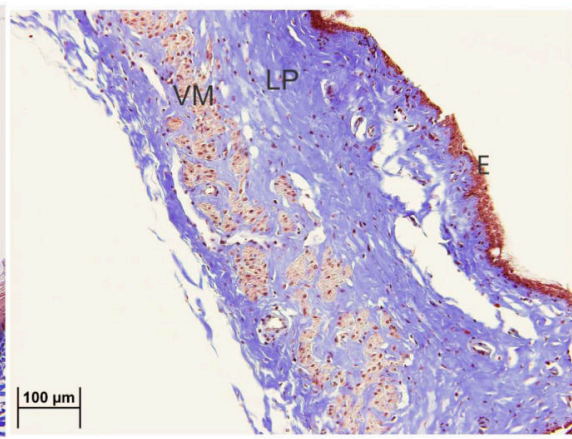

Ovariectomized

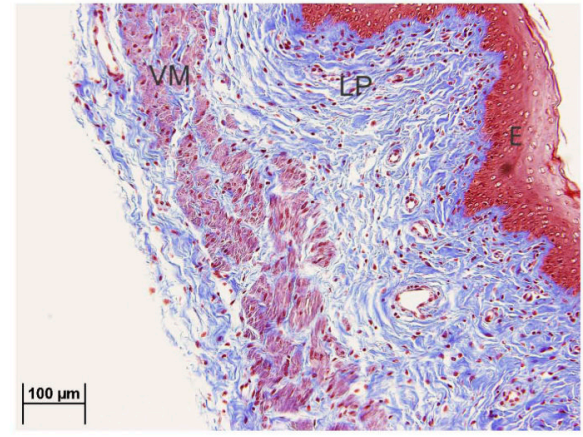

Ovariectomized + estrogen replaced

Figure 1.

Representative images (200x) of Masson's trichrome stained cross sections of the rat proximal vagina obtained from sham operated (sham); ovariectomized (Ovx) and ovariectomized with 1-week 17- $\beta$ estradiol treatment $(\mathrm{Ovx}+\mathrm{E})$. Ovariectomy resulted in an overall thinning of the vaginal wall, which was reversed by $17-\beta$ estradiol replacement. VM, vaginal muscularis; LP, lamina propria; E, epithelium. 


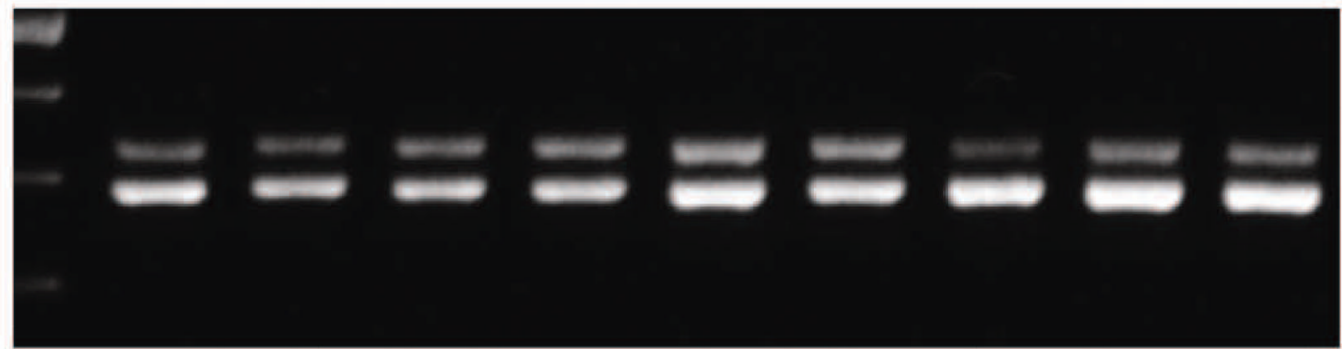
SM1

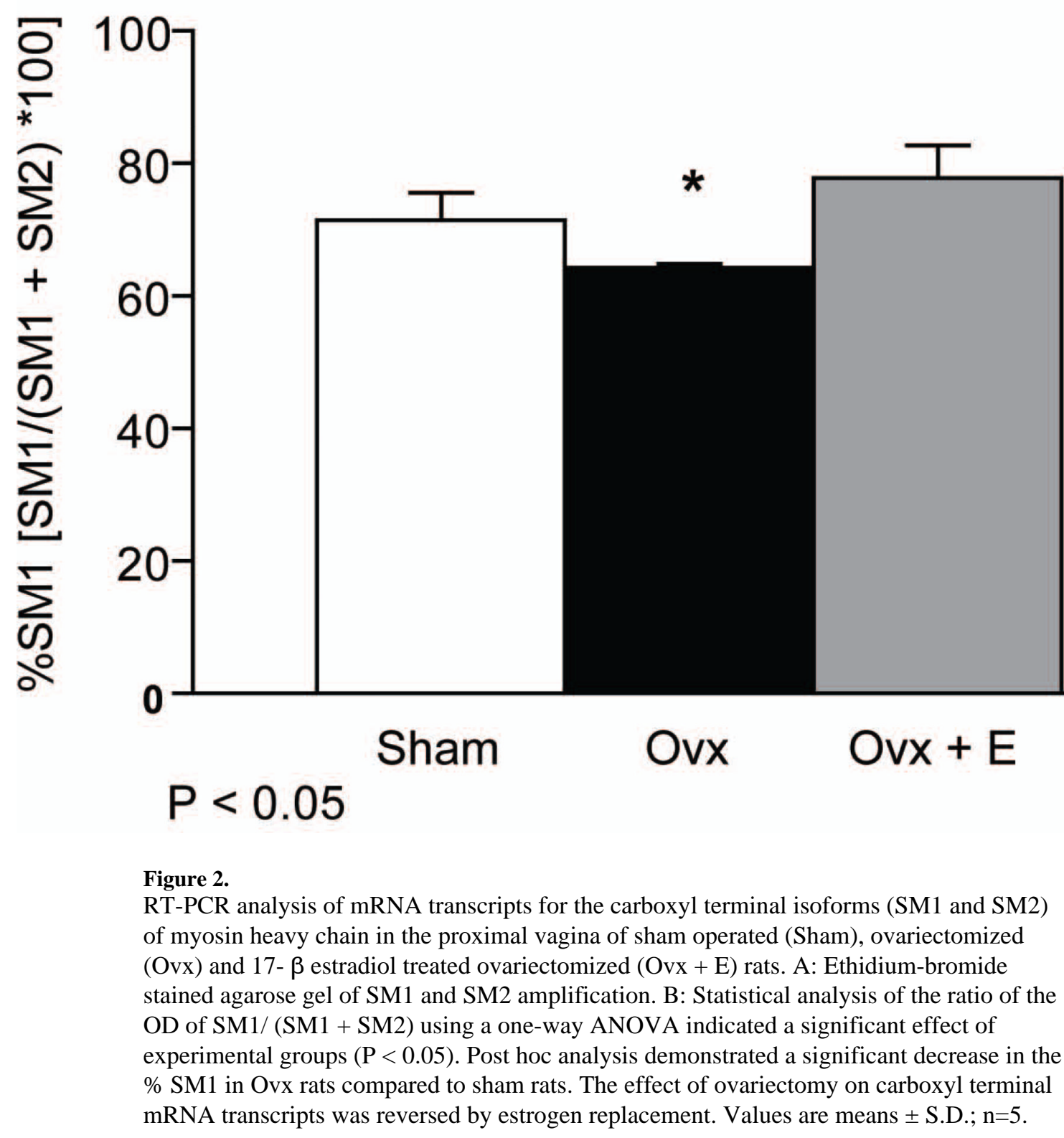




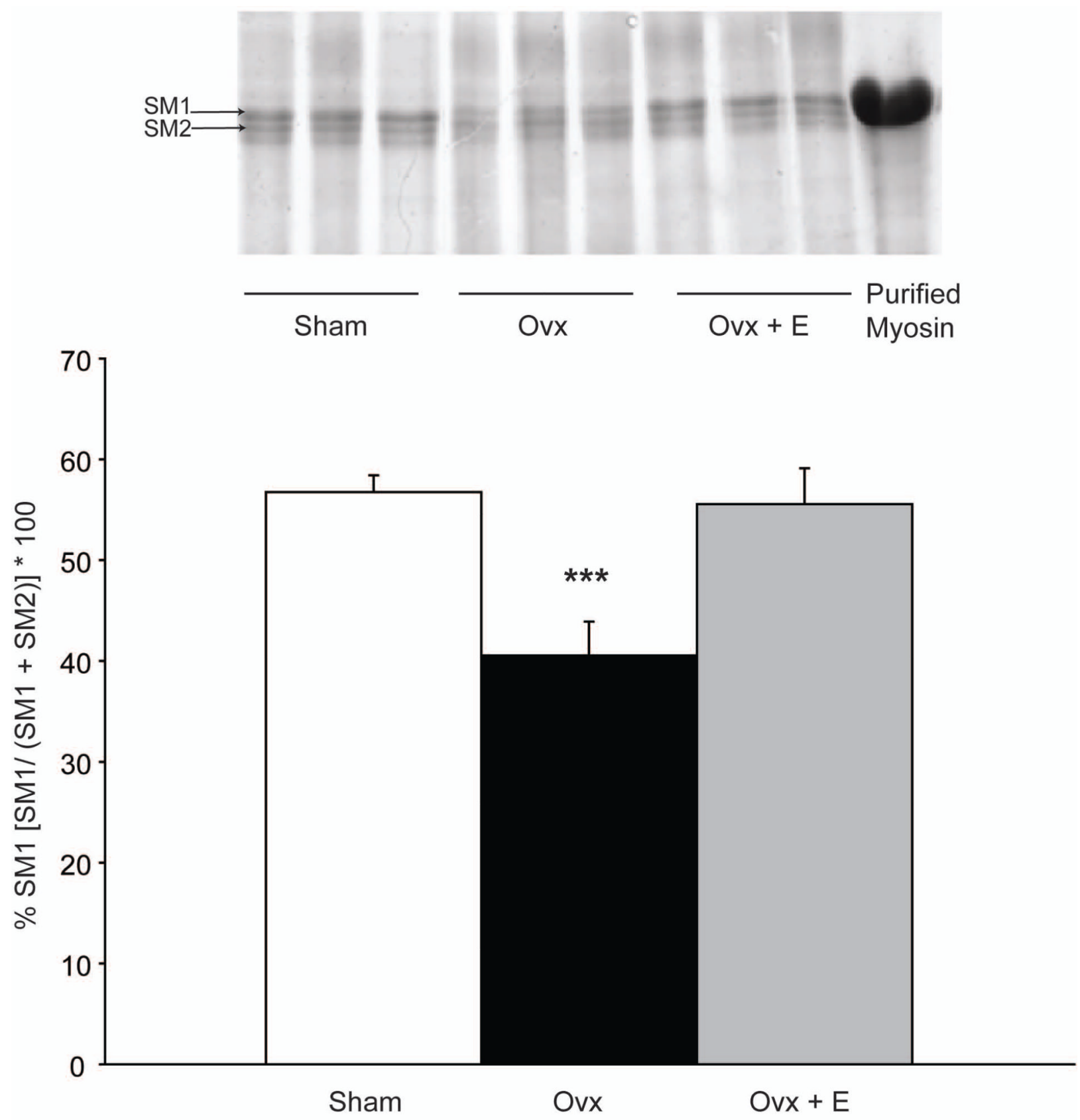

${ }^{* * *} \mathrm{P}<0.001$

Figure 3.

Analysis of protein expression of the $\mathrm{COOH}$ terminal isoforms (SM1 and SM2) of myosin heavy chain (MHC) in the proximal vagina of sham operated (sham, $n=5$ ), ovariectomized (ovx, $\mathrm{n}=5)$ and $17-\beta$ estradiol treated $(\mathrm{Ovx}+\mathrm{E}, \mathrm{n}=5)$ rats. A. Representative Coomassie stained gel demonstrating the separation of SM1 (upper band) and SM2 (middle band) isoforms of MHC. The lower band represents non-muscle myosin. B. Statistical analysis of the OD of SM1/(SM1 + SM2) using a one-way ANOVA indicated a significant effect of experimental groups $(\mathrm{P}<0.001)$ and was followed by post hoc analysis. Ovariectomy resulted in a significant decrease in the \% SM1 (P <0.001), which returned to sham levels following one week of $17-\beta$ estradiol treatment. Values are means \pm S.D.; $n=5$. 
150 kDa

75 kDa

42 kDa

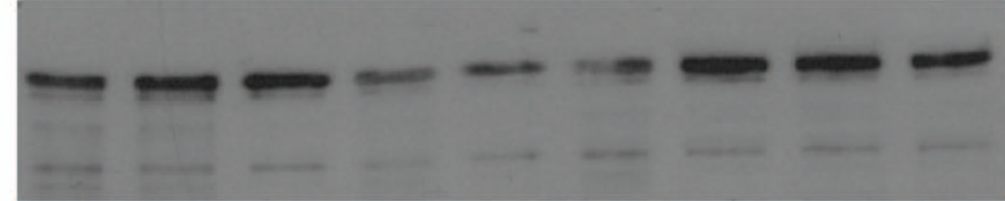

$h$-caldesmon

I-caldesmon

$\alpha$-actin

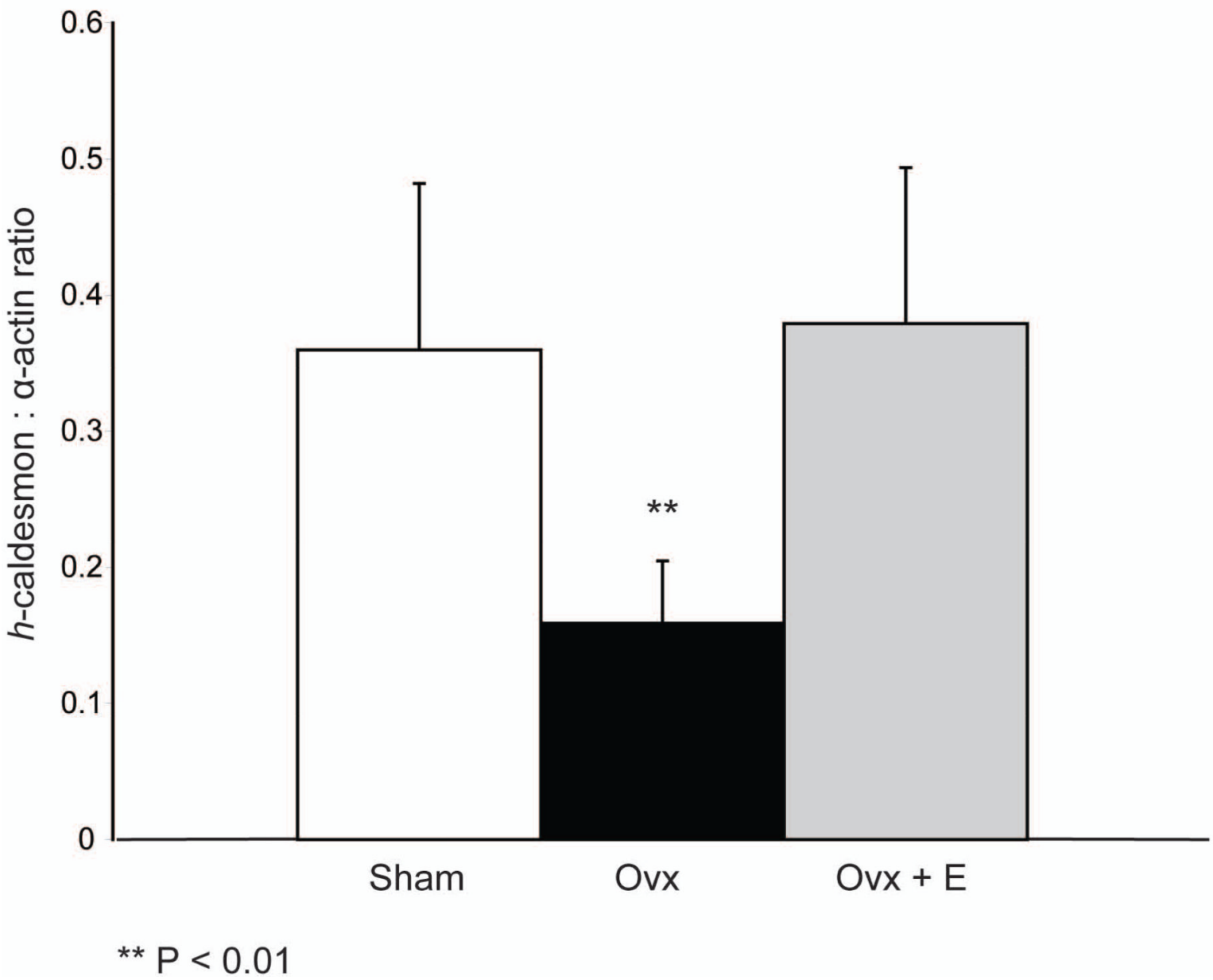

Figure 4.

Western blot analysis of $h$-caldesmon expression within the proximal vagina of sham operated (Sham), ovariectomized (Ovx) and ovariectomized with one week of 17- $\beta$ estradiol treated $(\mathrm{Ovx}+\mathrm{E}, \mathrm{n}=5)$ rats. A. Representative membrane of $h$-caldesmon, $l$-caldesmon and a-actin. B. Post hoc analysis of a significant one-way ANOVA indicated that ovariectomy significantly decreased the $h$-caldesmon/a-actin compared to sham operated rats $(\mathrm{P}<0.01)$. $h$-caldesmon protein expression returned to sham levels following one week of 17- $\beta$ estradiol replacement to ovariectomized animals. No significant differences were detected in l-caldesmon expression. Values are means \pm S.D.; $n=5$. 
Basha et al.

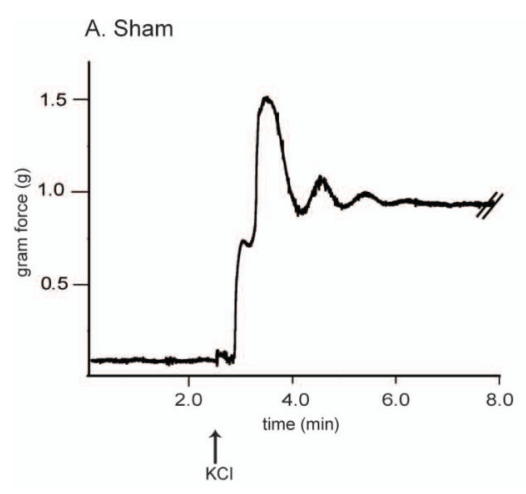

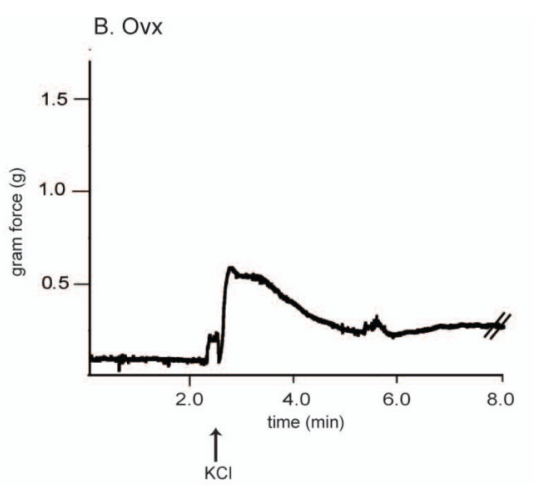

Figure 5.

Representative tracings of the contractile response of rodent proximal vaginal tissue strips to $110 \mathrm{mM} \mathrm{KCl}$. Strips were obtained from the proximal vagina of Sprague-Dawley rats that were sham-operated (Sham), ovariectomized (Ovx), and ovariectomized with 1-week 17- $\beta$ estradiol replacement $(\mathrm{Ovx}+\mathrm{E})$. 

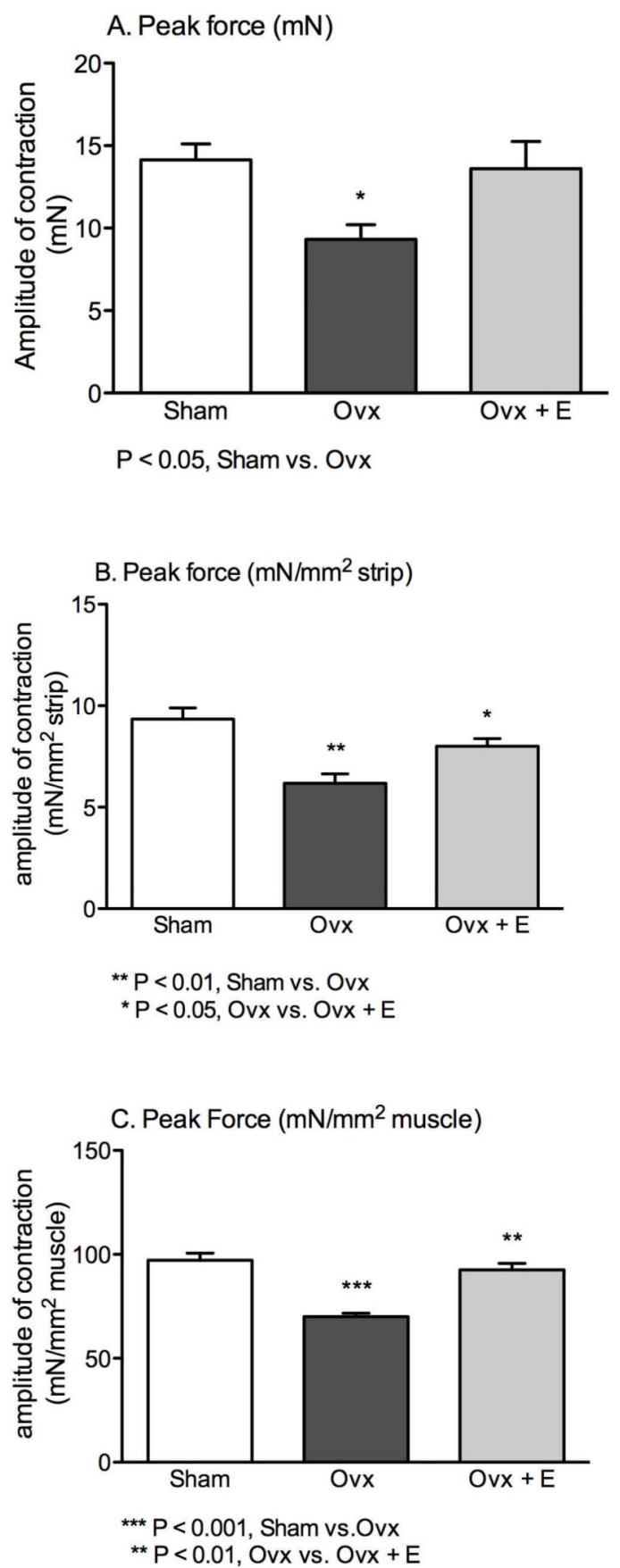

Figure 6.

Peak force in response to $110 \mathrm{mM} \mathrm{KCl}$ stimulation of proximal vaginal tissue strips obtained from rats that underwent a sham operation (sham, $n=5)$, ovariectomy (ovx, $n=5)$ or ovariectomy with one week of $17-\beta$ estradiol replacement $(\mathrm{Ovx}+\mathrm{E}, \mathrm{n}=5)$. A. Peak force $(\mathrm{mN})$ B. Peak force normalized to cross-sectional area of tissue strips $\left(\mathrm{mN} / \mathrm{mm}^{2}\right)$ C. Peak force normalized to cross-sectional area of muscle of tissue strips $\left(\mathrm{mN} / \mathrm{mm}^{2}\right)$. Ovariectomy resulted in a significant decrease in the amplitude of contraction compared to sham operated animals when peak force was expressed as $\mathrm{mN}, \mathrm{mN} / \mathrm{mm}^{2}$ tissue strip and $\mathrm{mN} / \mathrm{mm}^{2}$ muscle, an effect reversed by estrogen replacement. Values are means \pm S.D.; $n=5$. 


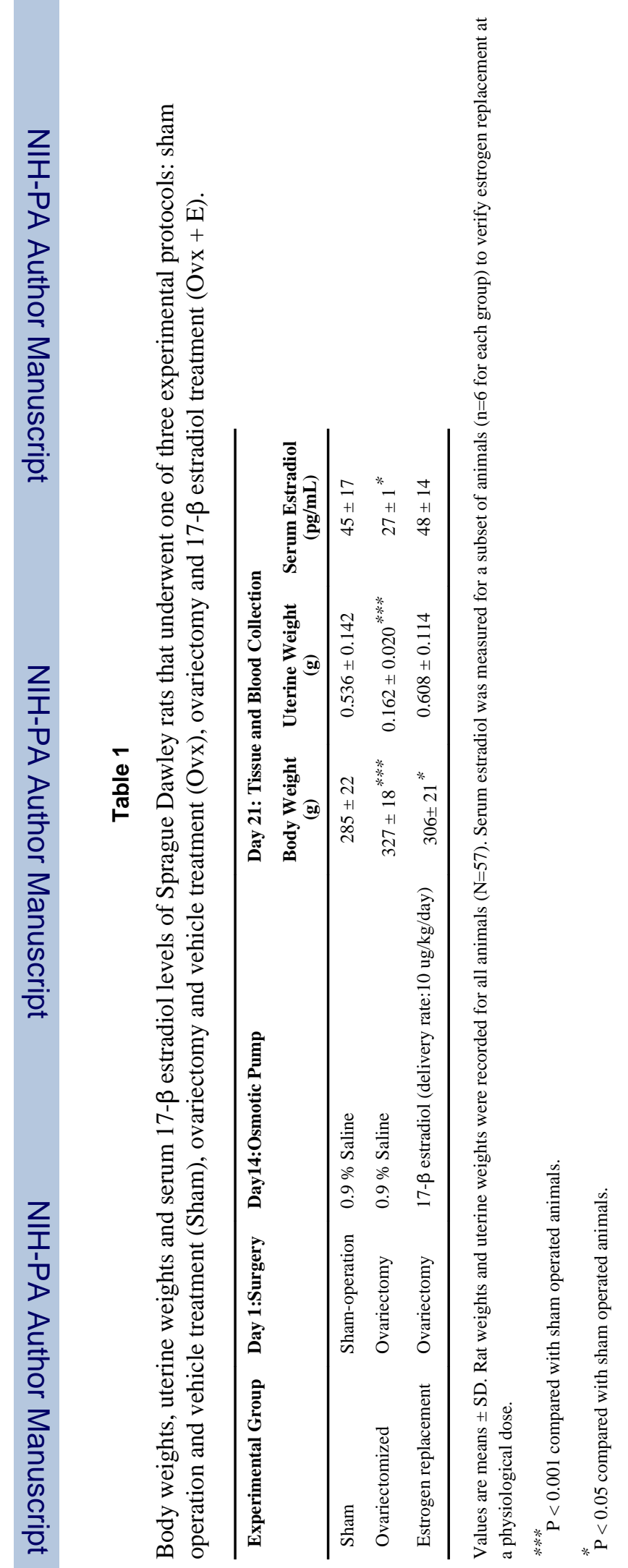

J Sex Med. Author manuscript; available in PMC 2014 May 01. 


\section{Table 2}

Estimated total cross-sectional area of tissue strips, cross-sectional area of vaginal muscularis, and calculated percentage of muscle of tissue strips obtained from the proximal vagina of female Sprague -Dawley rats that were sham-operated (Sham) ovariectomized (Ovx), and ovariectomized with 1-week 17- $\beta$ estradiol treatment $(\mathrm{Ovx}+\mathrm{E})$. Values are mean \pm S.D.; $\mathrm{n}=5$.

\begin{tabular}{lccc}
\hline Experimental Group & $\begin{array}{c}\text { Cross-sectional Area } \\
\text { Tissue Strip, } \mathbf{~ m m}^{2}\end{array}$ & $\begin{array}{c}\text { Cross-sectional Area } \\
\text { Muscle, } \mathbf{~ m m}^{2}\end{array}$ & $\begin{array}{c}\text { Cross-Sectional Area Muscle/Cross- } \\
\text { sectional Area of Strip, \% }\end{array}$ \\
\hline Sham-operated & $1.570 \pm 0.389$ & $0.148 \pm 0.029$ & $9.65 \pm 1.68$ \\
Ovariectomized & $1.516 \pm 0.248$ & $0.132 \pm 0.023$ & $8.82 \pm 1.29$ \\
Ovariectomized + Estradiol & $1.718 \pm 0.485$ & $0.147 \pm 0.037$ & $8.69 \pm 1.05$ \\
& N.S. & N.S. & N.S.
\end{tabular}

